\title{
Ethnic distance among the students of Serbia*
}

\author{
U. Šuvaković \\ University of Belgrade \\ Kraljice Natalije 43, Beograd, Serbia, 11000 \\ (e-mail: uros.suvakovic@uf.bg.ac.rs)
}

\begin{abstract}
The paper presents the results of the research aimed at identifying changes in ethnic distance among the students of Serbia. The starting point of the study was the author's belief that ethnic distance is a good indicator of inter-ethnic relations in multi-nation society and an indicator of conflict potential, and that ethnic distance is more stable provided social stability and open society. Ethnic distance was studied in the longitude project among Serbian students at the University in Kosovska Mitrovica five times in 2009-2016, twice - among the students in Belgrade (2010,2014), and once among the Albanian students in Priština (December 2016 - January 2017) based on the modified Bogardus scale, a part of the questionnaire in the students' native language and a number of surveys. The paper presents the results of the measurements of values constituting ethnic distance. The data reveal that the largest ethnic distance among Serbian students in Belgrade and in Kosovska Mitrovica was with the Albanians, while the smallest ethnic distance - with the Russians and Greeks. Among the Albanian students, the largest ethnic distance was with the Serbs, Romani and Russians, while the smallest — with the Americans and English. Certainly, the explanation should take into account the relations of these nations and official policies of their states including the self-proclamation of "Kosovo independence", and also the positions of these nations in the period of the disintegration of Yugoslavia, wars in the former Yugoslav states and the NATO aggression on Serbia. At the same time, the ethnic distances are extremely large in the territory of Kosovo and Metohija, however, with a tendency of decline among the Serbs. During the research in 2016 the beginning of 2017, the values of ethnic distance of the Serbian students from Kosovska Mitrovica to the Albanians and of the Albanian students from Priština to the Serbs were practically the same, especially the leading values of ethnic distance. When explaining the large ethnic distance with the Romani, it is necessary to remember about their social marginalization.
\end{abstract}

Key words: ethnic distance; Serbia; Kosovo and Metohija; students; surveys

The author of the idea of measuring social (ethnic) distance argued that "the social distance approach may have predictive value regarding possible outbreaks of intergroup hostilities and of possible developments of intergroup cooperation and assimilation" [4. P. 306]. When starting the longitude study of the social distance in the southern Serbian province Kosovo and Metohija, we referred to this idea of E. Bogardus. In this region, ethnic conflicts have lasted for centuries, and recently they have led to the development

* C U. Šuvaković, 2019.

The research is a part of the scientific project III 47023 "Kosovo and Metohija Between National Identity and Euro-integrations" financed by the Ministry of Education, Science and Technological Development of the Republic of Serbia.

The article was submitted on 15.02.2019. 
of a 'frozen conflict' and a 'divided society'. Tensions in ethnic relations are permanent $[11 ; 15]$, and, certainly, the facts from the social history are not the only determining factor here [3] for the memories of the population about the great difficulties are equally important as those happening every day $[13 ; 16$. P. 89—129]. All that affects the attitudes to the possible cooperation with members of other ethnic groups. Moreover, all this is a part of everyday culture of accepting differences that can hinder inter-ethnic dialogue and social integration.

As a rule, studies of social (ethnic) distance are conducted at the level of population as a whole, but we decided to measure ethnic distance only among the student youth due to three reasons. First, it is impossible to make a sample representing the whole population of Kosovo and Metohija for there are no relevant census data for decades: the Albanians boycotted census in 1991, the Serbs doubt the results of the census in 1981 and boycotted all censuses after 2000 organized by the international community. Certainly, some political practices do raise doubts in validity of the census data, for instance, in the first parliamentary elections after the proclamation of so-called 'Kosovo independence', less than $50 \%$ of the population voted. In a closed society such as the society of Kosovo Albanians, where the social control is tight, the rate of attendance indicates the inaccuracy of the electoral roll, i.e. the fact of its artificial increase. Second, the study of attitudes and measurement of ethnic distance among the students are especially important and significant for the student youth represent the most educated members of their nations that will become a basis of the future social and political elite [17. P. 292-293] responsible for "social development, dissemination of democratic cultural patterns and ideas of tolerance; therefore, students' willingness (or unwillingness) to cooperate with other nations forms the grounds for future cooperation (or conflict) in the region under study" [18. P. 250]. Historically, Albanian students in Priština had a significant role in starting the process that led to the disintegration of Yugoslavia [19]. Third, due to the fact that the statistical data on students is generally known, there is no way to manipulate them and it is easy to design a representative sample.

We conducted five measurements of ethnic distance in the north of Kosovo and Metohija among the students of Kosovska Mitrovica, mainly the Serbs. The surveys were conducted in 2009 [14], 2012, 2013, 2014 and in December of 2016. Besides Kosovska Mitrovica, the surveys were conducted twice (in 2010 and 2014) among the students of the University of Belgrade as an example of the stable social conditions and cosmopolitan environment. We used a sample representing the shares of students at the faculties, their gender and years of studies. We questioned from 310 to 400 students in Kosovska Mitrovica and Belgrade [8]. The sample was changed a little bit for the research of 2016-2017: all the elements remained the same as in previous surveys but the number of respondents was increased to 997 and divided into two groups: students of the north of Kosovo and Metohija, at the University in Kosovska Mitrovica, 402 respondents, and students of the Albanian University in Priština - 595 respondents. Every group was studied separately: the survey in Kosovska Mitrovica was conducted in December of 2016 and in Priština - in the second half of December of 2016 and 
in the beginning of January of 2017. In all surveys, the ethnic distance of students was measured in relation to former Yugoslav nations and minorities and also to some great nations outside the former Yugoslavia and contemporary Serbia.

From the very beginning, we faced political obstacles for conducting the study among Albanian students in Priština, that is why we managed partly to do it only in the fifth attempt in December 2016 - January 2017, and we will compare these data with the previous surveys' results. The possibility of comparative analysis is determined by the use of the same measuring instrument in all surveys - the Bogardus social distance scale modified for the student youth. The following social relations were offered to students to be estimated by their acceptability: marriage, friendship, accepting members of other ethnic groups as professors or assistants at the faculty, accepting them as a student of the same faculty, as neighbor, as a resident of the same city and as a citizen of the same state. The questionnaire was translated into Albanian for the survey in Priština and modified to reflect the social situation in the city.

The greatest ethnic distance of Serbian students from the north of Kosovo and Metohija in December 2016 was to the Albanians, then to the Turks, but in both cases it is the smallest in the period and is within the upper limit of the average distances (Table 1). In other words, Serbian students refuse 5 contacts out of 7 offered, while in previous years the average number of social contacts refused was 6 . This means that Serbian students agree to live with the Albanians in the same country (Serbia) and in the same city, which is a significant change for Kosovska Mitrovica is an ethnically divided city. When comparing this finding with the distance of Belgrade students identified in 2014 (Table 3), we can notice that their largest distance is also with the Albanians and Turks, but it is significantly smaller with a rather moderate distance with the Albanians) and even smaller distance with the Turks. This is not surprising: the surveys conducted in the last years of the 'great' socialist Yugoslavia [2] and later $[5 ; 9 ; 12]$ also revealed the largest ethnic distance to the Albanian national minority both among the youth and population in general.

The reduction of the ethnic distance with all nations was reveled in the survey of students in Kosovska Mitrovica in December 2016, however, except for the Macedonians - there was a slight increase (Table 1). This trend is typical for all nonYugoslav nations (Table 2). Nevertheless, the trend is not the same considering Belgrade students: there is an increase of ethnic distance with Yugoslav nations and minorities and with foreign nations (Table 3, 4).

Considering the former Yugoslav nations and national minorities, the ethnic distance of Belgrade students was within lower medium and low values (Table 3). However, their ethnic distance is slightly larger with those ex-Yugoslav nations with which the Serbs and Serbia had conflicts (Croats, Muslims/Bosnians). With foreign nations (nonYugoslav) the ethnic distance is always within low limits getting larger with the Americans, Germans and Chinese (Table 4). The smallest ethnic distance of Serbian students in all surveys - both in Kosovska Mitrovica and in Belgrade - was with the Russians and Greeks, and their ethnic distance is also small with the closest ex-Yugoslav nations - the Montenegrins and Macedonians. 
Average ethnic distance of students of the University in Priština with the temporary head-office in Kosovska Mitrovica (former Yugoslav nations and ethnic communities)

\begin{tabular}{|c|c|c|c|c|c|c|c|c|c|}
\hline $\begin{array}{c}2009 \\
\text { Nation / } \\
\text { ethnic } \\
\text { community }\end{array}$ & $\begin{array}{l}\text { Aver- } \\
\text { age } \\
\text { dis- } \\
\text { tance }\end{array}$ & 2012 & $\begin{array}{l}\text { Aver- } \\
\text { age } \\
\text { dis- } \\
\text { tance }\end{array}$ & 2013 & $\begin{array}{l}\text { Aver- } \\
\text { age } \\
\text { dis- } \\
\text { tance }\end{array}$ & 2014 & $\begin{array}{l}\text { Aver- } \\
\text { age } \\
\text { dis- } \\
\text { tance }\end{array}$ & $\begin{array}{c}\text { December } \\
2016\end{array}$ & $\begin{array}{l}\text { Aver- } \\
\text { age } \\
\text { dis- } \\
\text { tance }\end{array}$ \\
\hline 1. Albanians & 5.85 & 1. Albanians & 6.09 & 1. Albanians & 5.53 & 1. Albanians & 5.74 & 1. Albanians & 4.95 \\
\hline 2. Turks & 4.91 & 2. Turks & 5.48 & 2. Croats & 5.07 & 2. Croats & 4.83 & 2. Turks & 4.33 \\
\hline 3. Croats & 4.55 & 3. Croats & 4.52 & 3. Turks & 4.94 & 3. Turks & 4.76 & 3. Croats & 4.16 \\
\hline $\begin{array}{l}\text { 4. Bosnians / } \\
\text { Muslims }\end{array}$ & 4.04 & $\begin{array}{l}\text { 4. Bosnians / } \\
\text { Muslims }\end{array}$ & 5.16 & 4. Romani & 4.70 & $\begin{array}{l}\text { 4. Hunga- } \\
\text { rians }\end{array}$ & 4.10 & $\begin{array}{l}\text { 4. Bulga- } \\
\text { rians }\end{array}$ & 3.50 \\
\hline 5. Romani & 4.04 & $\begin{array}{l}\text { 5. Hungari- } \\
\text { ans }\end{array}$ & 4.86 & $\begin{array}{l}\text { 5. Hunga- } \\
\text { rians }\end{array}$ & 4.53 & $\begin{array}{c}\text { 5. Bosnians / } \\
\text { Muslims }\end{array}$ & 4.02 & $\begin{array}{l}\text { 5. Hunga- } \\
\text { rians }\end{array}$ & 3.34 \\
\hline $\begin{array}{l}\text { 6. Hunga- } \\
\text { rians }\end{array}$ & 3.77 & 6. Bulgarians & 4.78 & $\begin{array}{l}\text { 6. Bosnians / } \\
\text { Muslims }\end{array}$ & 4.27 & $\begin{array}{l}\text { 6. Bulga- } \\
\text { rians }\end{array}$ & 3.88 & $\begin{array}{l}\text { 6. Bosnians / } \\
\text { Muslims }\end{array}$ & 3.21 \\
\hline 7. Bulgarians & 3.69 & 7. Romanians & 4.65 & $\begin{array}{c}\text { 7. Bulga- } \\
\text { rians }\end{array}$ & 4.24 & $\begin{array}{l}\text { 7. Roma- } \\
\text { nians }\end{array}$ & 3.72 & $\begin{array}{l}\text { 7. Roma- } \\
\text { nians }\end{array}$ & 3.20 \\
\hline $\begin{array}{l}\text { 8. Romani- } \\
\text { ans } \\
\end{array}$ & 3.64 & 8. Romani & 4.28 & $\begin{array}{l}\text { 8. Roma- } \\
\text { nians }\end{array}$ & 4.11 & 8. Romani & 3.71 & 8. Romani & 3.17 \\
\hline $\begin{array}{l}\text { 9. Slove- } \\
\text { nians }\end{array}$ & 3.16 & $\begin{array}{c}\text { 9. Slove- } \\
\text { nians }\end{array}$ & 3.95 & $\begin{array}{c}\text { 9. Slove- } \\
\text { nians }\end{array}$ & 3.92 & $\begin{array}{c}\text { 9. Slove- } \\
\text { nians }\end{array}$ & 2.93 & $\begin{array}{l}\text { 9. Slove- } \\
\text { nians }\end{array}$ & 2.71 \\
\hline \begin{tabular}{|l|} 
10. Macedo- \\
nians \\
\end{tabular} & 2.32 & $\begin{array}{l}\text { 10. Macedo- } \\
\text { nians }\end{array}$ & 2.76 & $\begin{array}{l}\text { 10. Macedo- } \\
\text { nians }\end{array}$ & 3.03 & $\begin{array}{l}\text { 10. Macedo- } \\
\text { nians }\end{array}$ & 1.94 & $\begin{array}{l}\text { 10. Macedo- } \\
\text { nians } \\
\end{array}$ & 2.00 \\
\hline \begin{tabular}{|c} 
11. Monte- \\
negrins
\end{tabular} & 2.00 & $\begin{array}{c}\text { 11. Monte- } \\
\text { negrins }\end{array}$ & 1.92 & $\begin{array}{c}\text { 11. Monte- } \\
\text { negrins }\end{array}$ & 1.94 & $\begin{array}{c}\text { 11. Monte- } \\
\text { negrins }\end{array}$ & 1.85 & $\begin{array}{c}\text { 11. Monte- } \\
\text { negrins }\end{array}$ & 1.65 \\
\hline 12. Serbs & 0.16 & 12. Serbs & 0.27 & 12. Serbs & 0.31 & 12. Serbs & 0.59 & 12. Serbs & 0.26 \\
\hline
\end{tabular}

\section{Average ethnic distance of students of the University in Priština with the temporary head-office in Kosovska Mitrovica (some non-Yugoslav nations)}

\begin{tabular}{|c|c|c|c|c|c|c|c|c|c|}
\hline $\begin{array}{c}2009 \\
\text { Nation }\end{array}$ & $\begin{array}{l}\text { Aver- } \\
\text { age } \\
\text { dis- } \\
\text { tance }\end{array}$ & 2012 & $\begin{array}{l}\text { Aver- } \\
\text { age } \\
\text { dis- } \\
\text { tance }\end{array}$ & 2013 & $\begin{array}{c}\text { Aver- } \\
\text { age } \\
\text { dis- } \\
\text { tance }\end{array}$ & 2014 & $\begin{array}{l}\text { Aver- } \\
\text { age } \\
\text { dis- } \\
\text { tance }\end{array}$ & $\begin{array}{c}\text { December } \\
2016\end{array}$ & $\begin{array}{l}\text { Aver- } \\
\text { er- } \\
\text { age } \\
\text { dis- } \\
\text { tance }\end{array}$ \\
\hline $\begin{array}{l}\text { 1. Ameri- } \\
\text { cans }\end{array}$ & 4.50 & 1. Germans & 5.19 & $\begin{array}{l}\text { 1. Ameri- } \\
\text { cans }\end{array}$ & 4.78 & 1. Germans & 4.48 & 1. Germans & 3.98 \\
\hline 2. Germans & 4.29 & $\begin{array}{l}\text { 2. Ameri- } \\
\text { cans }\end{array}$ & 4.97 & 2. Germans & 4.48 & $\begin{array}{l}\text { 2. Ameri- } \\
\text { cans }\end{array}$ & 4.37 & 2. Americans & 3.86 \\
\hline 3. Chinese & 4.25 & 3. Dutch & 4.78 & 3. Dutch & 4.47 & 3. Dutch & 3.91 & $\begin{array}{l}\text { 3. English- } \\
\text { men }\end{array}$ & 3.49 \\
\hline 4. Dutch & 3.90 & 4. Poles & 4.74 & $\begin{array}{l}\text { 4.English- } \\
\text { men }\end{array}$ & 4.37 & $\begin{array}{l}\text { 4. English- } \\
\text { men }\end{array}$ & 3.80 & 4. Dutch & 3.28 \\
\hline $\begin{array}{l}\text { 5. English- } \\
\text { men }\end{array}$ & 3.82 & 5. Chinese & 4.53 & 5. Chinese & 4.21 & 5. Poles & 3.80 & 5. Poles & 3.17 \\
\hline 6. Poles & 3.61 & $\begin{array}{l}\text { 6. English- } \\
\text { men }\end{array}$ & 4.46 & 6. Poles & 4.20 & 6. French & 3.60 & 6. French & 3.16 \\
\hline 7. French & 3.45 & 7. French & 4.07 & 7. French & 4.00 & 7. Chinese & 3.35 & 7. Chinese & 3.11 \\
\hline 8. Greeks & 1.82 & 8. Greeks & 2.68 & 8. Greeks & 2.90 & 8. Greeks & 1.57 & 8. Italians & 2.79 \\
\hline \multirow[t]{3}{*}{ 9. Russians } & 1.76 & 9. Russians & 1.37 & 9. Russians & 1.94 & 9. Russians & 1.34 & 9. Spaniards & 2.33 \\
\hline & & & & & & & & 10. Greeks & 1.43 \\
\hline & & & & & & & & 11. Russians & 1.07 \\
\hline
\end{tabular}


Average ethnic distance of students of the University of Belgrade

(former Yugoslav nations and ethnic communities)

\begin{tabular}{|c|c|c|c|}
\hline $\begin{array}{c}2010 \\
\text { Nation / Ethnic community }\end{array}$ & $\begin{array}{l}\text { Average } \\
\text { distance }\end{array}$ & $\begin{array}{c}2014 \\
\text { Nation / Ethnic community }\end{array}$ & $\begin{array}{l}\text { Average } \\
\text { distance }\end{array}$ \\
\hline 1. Albanians & 3.80 & 1. Albanians & 3.43 \\
\hline 2. Turks & 2.32 & 2. Turks & 2.31 \\
\hline 3. Romani & 2.30 & 3. Romani & 2.25 \\
\hline 4. Croats & 2.15 & 4. Bosnians / Muslims & 2.22 \\
\hline 5. Bulgarians & 1.74 & 5. Croats & 2.16 \\
\hline 6. Bosnians / Muslims & 1.68 & 6. Bulgarians & 1.83 \\
\hline 7. Romanians & 1.58 & 7. Hungarians & 1.67 \\
\hline 8. Hungarians & 1.56 & 8. Romanians & 1.64 \\
\hline 9. Montenegrins & 1.39 & 9. Slovenians & 1.39 \\
\hline 10. Slovenians & 1.36 & 10. Macedonians & 1.11 \\
\hline 11. Macedonians & 0.90 & 11. Montenegrins & 0.88 \\
\hline 12. Serbs & 0.18 & 12. Serbs & 0.31 \\
\hline
\end{tabular}

Average ethnic distance of students of the University of Belgrade (some non-Yugoslav nations)

\begin{tabular}{|c|c|c|c|}
\hline $\begin{array}{c}2010 \\
\text { Nation }\end{array}$ & $\begin{array}{l}\text { Average } \\
\text { distance }\end{array}$ & $\begin{array}{c}2014 \\
\text { Nation }\end{array}$ & $\begin{array}{l}\text { Average } \\
\text { distance }\end{array}$ \\
\hline 1. Chinese & 2.38 & 1. Americans & 1.73 \\
\hline 2. Americans & 1.61 & 2. Germans & 1.63 \\
\hline 3. Germans & 1.47 & 3. Chinese & 1.56 \\
\hline 4. Dutch & 1.43 & 4. Dutch & 1.45 \\
\hline 5. Englishmen & 1.23 & 5. Englishmen & 1.43 \\
\hline 6. Poles & 1.23 & 6. Poles & 1.39 \\
\hline 7. French & 1.05 & 7. French & 1.26 \\
\hline 8. Russians & 0.86 & 8. Greeks & 0.90 \\
\hline 9. Greeks & 0.72 & 9. Russians & 0.85 \\
\hline
\end{tabular}

Table 5

Average ethnic distance of the Albanian students of the University in Priština

\begin{tabular}{|rl|c|}
\hline \multicolumn{2}{|c|}{$\begin{array}{c}\text { January } \mathbf{2 0 1 7} \\
\text { Nation / Ethnic community }\end{array}$} & Average distance \\
\hline 1. & Serbs & 4.59 \\
\hline 2. & Romani & 4.45 \\
\hline 3. & Russians & 4.23 \\
\hline 4. & Romanians & 4.20 \\
\hline 5. & Hungarians & 4.10 \\
\hline 6. & Bulgarians & 4.08 \\
\hline 7. & Macedonians & 4.04 \\
\hline 8. & Chinese & 4.03 \\
\hline 9. & Greeks & 4.02 \\
\hline 10. & Montenegrins & 4.01 \\
\hline 11. & Turks & 3.97 \\
\hline 12. & Spaniards & 3.95 \\
\hline 13. & Poles & 3.94 \\
\hline 14. & Slovenians & 3.92 \\
\hline 15. & Croats & 3.88 \\
\hline 16. & Bosnians / Muslims & 3.88 \\
\hline 17. & Dutch & 3.87 \\
\hline 18. & French & 3.81 \\
\hline 19. & Germans & 3.79 \\
\hline 20. & Italians & 3.79 \\
\hline 21. & Englishmen & 3.78 \\
\hline 22. & Americans & 3.75 \\
\hline 23. & Albanians & 3.70 \\
\hline & & \\
\hline
\end{tabular}


The first study of ethnic distance among the Albanian students in Priština was conducted in December 2016 - January 2017; therefore, we are not able to compare the results in general but we can compare the ethnic distances of Serbian students from Kosovska Mitrovica with Albanian students in Priština. We should mention that only 275 answered the question on ethnic distance, which is only $50 \%$ of the sample. Such a low response rate can be explained by both social pressure and lack of desire to complete the questionnaire. Table 5 shows that the largest ethnic distance of the Albanian students in Priština is with the Serbs, Romani and Russians. It is also significant that the self-distance of the Albanian students is 3.70 and the distance with the Serbs - 4.59. Among other nations, the Americans and English are the closest for Albanian students.

When comparing the data of the study of ethnic distance of Serbian students from Kosovska Mitrovica to the Albanians in 2016 (Table 1) and of Albanian students from Priština to the Serbs in 2016/2017 (Table 5), one can see that their ethnic distances is almost the same. The ethnic distance of Serbian students with the Albanians is only by 0.36 larger than the ethnic distance of Albanian students with the Serbs. Regularity should be noticed: for the nations to which Serbian students from Kosovska Mitrovica express a larger social distance, Albanian students from Priština, on the contrary, express a smaller social distance. However, the values of ethnic distance are similar. The most distinctive difference considering both the rank and the value is the ethnic distance with the Russians and the Romani. Serbian students showed the smallest ethnic distance to the Russians as compared with other nations except the Serbs, and the Greeks are very close to the Russians; while Albanian students from Priština showed the greatest distance to the Serbs, Romani and then to the Russians.

It should be mentioned that there was a significant reduction of ethnic distance to the Romani among Serbian students in Kosovska Mitrovica in 2016 (Table 1), which was also the case among students in Belgrade in 2014 although the reduction was significantly lower (Table 3). However, the value of ethnic distance of students in Belgrade to the Romani is the lowest not only compared with the students from Kosovska Mitrovica and Priština but also compared with the students in Veliko Trnovo (Bulgaria), Bitolj (Macedonia) and Niš (Serbia) [10], while in Priština this ethnic distance is the largest among the students of the universities under study. A significant reduction of ethnic distance to the Romani people among the students in Kosovska Mitrovica should be interpreted as a result (a) of political activities within the project 'Decade of the Romani' announced by the Government of the Republic of Serbia (this refers to the distance of students in Niš and Belgrade), and (b) of awareness of the same destiny of the Romani and Serbs in Kosovo and Metohija (both were ethnically deported from Kosovo in 1999 and then in 2004 within the project of creating ethnically clean Kosovo supported by the Albanian separatists).

$$
* * *
$$

We believe that monitoring of the ethnic distance (attitudes to other nations) is very useful in the region of Kosovo and Metohija. The reduction of ethnic distance among Serbian students and its moderate values when considering the Albanians four years after signing the Brussels Agreement show that the attempts to politically regulate 
the relations of the Serbs and Albanians make some sense. Certainly, it would be better if the values of the ethnic distance were even smaller, similar to the students in Belgrade or to the earlier identified among the population of the northern province of Serbia Vojvodina [6], which would indicate a decline of the conflict potential. Unfortunately, political actions of the beginning of 2019 will probably contribute to the growth of ethnic distance, which we shall examine in the further research.

Nevertheless, the fact that the values and ranks of ethnic distance of Serbian students from Kosovska Mitrovica to the Albanians and of Albanian students from Priština to the Serbs are practically the same, proves that, despite the divided territory, there are significant mutual social and political factors that influence the ethnic distance. Moreover, it is clear that ethnic distance among both ethnic groups in two university centers - Kosovska Mitrovica and Priština, an ethnically divided society, is also determined by the positions of other nations and their states on the so-called 'Kosovo independence'. Thus, with the nations that showed solidarity with the Serbs during the disintegration of Yugoslavia and NATO aggression, especially if they refused to recognize the independent Kosovo, Serbian students have the smallest ethnic distance, which refers especially to the Russians and Greeks. The same applies to Belgrade students with even lower values. On the other hand, among Albanian students in Priština, the largest ethnic distance is with the Romani people, which has a different explanation, and the Russians, whom the Albanians consider the most important Serbian ally in the struggle to keep Kosovo and Metohija as part of Serbia. Likewise, the smallest distance the students in Priština show to the Americans and English who are considered the actors of the NATO aggression against Serbia and supporters of the so-called 'Kosovo independence'.

The results of the survey in Belgrade prove that a stable value of the ethnic distance can be achieved only in stable conditions: the more open and more cosmopolitan society, the smaller the ethnic distance.

The fact that about a half of the students in Priština refused to answer the question on the ethnic distance raises many research questions. However, we believe that the main problem was that they did not know what answer was socially desirable. Certainly, the study of ethnic distance among Albanian students in Priština should be repeated together with the survey in the north of Kosovo and Metohija in order to get objective data for the comparative analysis of the social distance in a closed society with strong social control and the tendency to social mimicry of attitudes especially with political connotations.

The attitudes to the Romani is a very interesting indicator pointing primarily to their socially marginalized position — poverty 'sub-class' and 'sub-proletarian' status [7], i.e. the Romani "remain without a possibility to use channels of social mobility and ways of serious social organizations aimed at changing their social position" [20. P. 97]. However, political reasons should not be ignored especially considering the strive of the Albanian separatists for the 'ethnically clean' Kosovo and the fact that the greatest ethnic distance was reveled among the Albanian student in Priština (compared with ethnic distances of students in Belgrade, Nis, Kosovska Mitrovica, Veliko Trnovo and Bitolj). However, it does not explain a relatively large distance of the Albanian students with their own nation, which is partly proved by the fact that in the first quarter of 2015 
the greatest number of the Albanians from Kosovo asked for asylum in the EU (almost 48,900 , or $26 \%$ out of the total number of seekers the asylum), only then the Syrians follow (16\%), Afghans (7\%) and asylum seekers from other regions [1]. Perhaps, this is an indicator of a dissatisfaction of the Albanians with the conditions of life in Kosovo and Metohija, for which students blame their compatriots. We hope that further studies will give the answers to this and other questions.

\section{References}

[1] Asylum in the EU in the first quarter of 2015: 185,000 first time asylum seekers in the EU in the first quarter of 2015 - half are Kosovars, Syrians or Afghans. http://ec.europa.eu/ eurostat/documents/2995521/6887997/3-18062015-CP-EN.pdf/4457b050-26f9-4cf1-bf27$9 \mathrm{ffb} 73 \mathrm{ff} 8 \mathrm{c} 7 \mathrm{~b} 28.02 .2016$.

[2] Baćević Lj. National consciousness of the youth. Mihailović S. at al. (Eds.) Children of Crisis Youth of Yugoslavia in the late 1980s. Beograd; 1990 (In Serbian).

[3] Bazić J. The role of the Kosovo myth in shaping Serbian national identity. Srpska Politička Misao. 2012; 4 (In Serbian).

[4] Bogardus E.S. Measurement of personal-group relations. Sociometry. 1947; 10 (4).

[5] Kuzmanović B. Social distance with different nations. Lazić M. (Ed.). Destruction of Society. Beograd; 1994 (In Serbian).

[6] Lazar Ž., Koković D. Ethnical distance in Vojvodina: Results of the research. Sociološki Pregled. 2005; 39 (3) (In Serbian).

[7] Mitrović A. At the Bottom: The Romani at the Risk of Poverty. Beograd; 1990 (In Serbian).

[8] Petrović J. On the methodology of empirical research (sample, questionnaire and field stage). Šuvaković U, Petrović J. (Eds.). Students in the North of Kosovo and Metohija. Kosovska Mitrovica; 2016 (In Serbian).

[9] Petrović J., Miladinović S. Profile of the ethnic distancing among students of the University of Niš. Dimitrijević B. (Ed.). Historiography and Contemporary University. Vol. 1. Niš; 2014 (In Serbian).

[10] Petrović J., Šuvaković U. Social distance of students from Serbia, Macedonia and Bulgaria with the Romani. Godišnjak za Sociologiju. 2016; 11 (In Serbian).

[11] Petrović J. Interethnic relations in Kosovo and Metohija studied through the ethnic distance prism. Maliković D. (Ed. in chief). Kosovo and Metohija in Civilization Processes. Vol. 4. Šuvaković U. (Ed.). Sociology and Other Social Sciences. Kosovska Mitrovica; 2010 (In Serbian).

[12] Popadić D. A way from fraternity and unity - ethnic distance of citizens of Serbia. Mihailović S. (Ed.). How Citizens of Serbia Define Transition: A Public Opinion Poll. Beograd; 2010 (In Serbian).

[13] Sotirović V.B. Kosovo \& Metohija: Ten years after the 'March Pogrom 2004'. Srpska Politička Misao. 2014; 1 (In Serbian).

[14] Šuvaković U. A sketch of the ethno-political views of the Serbian students in Kosovo. Sotsiologicheskie Issledovaniya. 2010; 3 (In Russ.).

[15] Šuvaković U. Century of separatist violence of the Kosovo Albanians against the Serbs and other citizens of non-Albanian nationality (1912-2012). Maliković D, Šuvaković U., Stevanović O. (Eds.). Political Violence. Kosovska Mitrovica; 2011 (In Serbian).

[16] Šuvaković U. Serbia in the Era of Changes. Moscow; 2016 (In Russ.).

[17] Šuvaković U., Petrović J. Attitudes to Kosovo and Metohija and estimates of the most important global goals of Serbia: Comparative analysis of the students' attitudes in the Univeristy in Priština with temporary head office in Kosovska Mitrovica and the University of Belgrade. Zbornik Radova Filozofskog Fakulteta u Prištini. 2010; 40 (In Serbian). 
[18] Šuvaković U., Petrović J. Ethnic distance expressed by students in northern Kosovo and Metohija in a longitudinal coparative study. Srpska Politička Misao. 2014; 4 (In Serbian).

[19] Šuvaković U., Stevanović O. Separatist rebellion of the Albanian students in Kosovo and Metohija in 1981 as the beginning of the socialist Yugoslavia breakdown. Sociološki Pregled. 2018; 52 (4) (In Serbian).

[20] Todorović D. Social Distance with the Romani. Niš; Novi Sad; 2007 (In Serbian).

DOI: $10.22363 / 2313-2272-2019-19-2-203-211$

\title{
Этническая дистанция студентов Сербии*
}

\author{
У. Шувакович \\ Белградский университет \\ ул. Королевы Натальи, 43, Белград, Сербия, 11000 \\ (e-mail: uros.suvakovic@uf.bg.ac.rs)
}

\begin{abstract}
В статье представлены результаты исследования, целью которого было выявление и объяснение изменений этнической дистанции у студентов Сербии. Отправной точкой проекта было убеждение автора, что этническая дистанция - хороший индикатор межэтнических отношений в любом многонациональном обществе, а также индикатор накопившегося в нем конфликтного потенциала, потому что этническая дистанция наиболее устойчива в обществах, которые можно уверенно квалифицировать как открытые и социально стабильные. Этническая дистанция была эмпирически изучена в ходе лонгитюдного проекта: было проведено пять ее замеров среди сербских студентов Университета Косовской Митровицы (2009-2016), два замера - среди студентов Белграда $(2010,2014)$ и один замер - среди албанских студентов Приштины (декабрь 2016 январь 2017). Все опросы были основаны на шкале социальной дистанции Богардуса, часть опросника предлагалась студентам на их родном языке, и была реализована целая серия опросов. В статье представлены результаты измерения ценностей, задающих этническую дистанцию. Согласно полученным данным, наибольшая этническая дистанция наблюдается у сербских студентов Белграда и Косовской Митровицы по отношению к албанцам, тогда как наименьшая - с русскими и греками. Напротив, албанские студенты демонстрируют наибольшую этническую дистанцию по отношению к сербам, цыганам и русским, а наименьшую - к американцам и англичанам. Безусловно, для объяснения этих данных необходимо учитывать взаимоотношения государств и их официальную политику, особенно оценку ими самопровозглашенной независимости Косово и агрессии НАТО против Сербии, а также их позиции в годы распада Югославии и войн между бывшими югославскими республиками. Следует отметить крайне большую этническую дистанцию в Косово и Метохии, однако с тенденцией ее снижения у сербских студентов. Так, опрос в конце 2016 - начале 2017 года показал, что ценности, задающие этническую дистанцию у сербских студентов Косовской Митровицы по отношению к албанцам, а также у албанских студентов Приштины по отношению к сербам, оказались предельно схожими, особенно наиболее частотные. Когда речь заходит о значительной этнической дистанции по отношению к цыганам в Сербии, то необходимо помнить об их социальной маргинализации.
\end{abstract}

Ключевые слова: этническая дистанция; Сербия; Косово и Метохия; студенты; опросы

* (С) Шувакович У., 2019.

Исследование является частью научного проекта III 47023 «Косово и Метохия между национальной идентичностью и евроинтеграцией», реализованного при финансовой поддержке Министерства образования, науки и технологического развития Республики Сербия.

Статья поступила в редакциюю 15.02.2019. 